\title{
Analysis of behavior and determinants of cost stickiness in manufacturing companies in Indonesia
}

\author{
Farizy Yunaz \& Catur Sasongko \\ Department of Accounting, Faculty of Economics and Business, Universitas Indonesia, Depok, Indonesia
}

\begin{abstract}
This research aims to provide the empirical evidence regarding cost stickiness behavior and its determinants in listed manufacturing companies. Hypothesis testing is performed using the pooled least square method. The result concludes that there is cost stickiness behavior in selling, general, and administrative costs. In terms of determinants, firm specific adjustment costs measured by asset intensity and employee intensity have a positive significant impact on the level of cost stickiness. Meanwhile, earnings target and leverage have a negative significant impact on the level of cost stickiness. However, the management empire building incentives measured by free cash flow has no positive significant impact.
\end{abstract}

\section{INTRODUCTION}

In a traditional cost behavior concept, costs are classified into fixed cost and variable cost, which are assumed to have a proportional relationship with the level of activities. These costs may either increase or decrease according to the change in activities (Noreen, 1991). In fact, previous studies have suggested that the traditional cost behavior assumption does not fully apply. Cooper and Kaplan (1998) find that there are differences in the cost behavior response from its activities since management has the desire to increase the cost changes more when activities are rising than when activities are declining. Anderson et al. (2003) find that selling, general, and administrative costs respond to upward or downward changes in activity. This condition is referred to as cost stickiness behavior. The increase of these costs when revenues increase is higher compared to the decrease caused by the decline in revenues by an equivalent amount. This cost stickiness behavior is influenced by several factors. Firm-specific adjustment costs measured by asset intensity and employee intensity as suggested by Anderson et al. (2003) have a positive impact on cost stickiness. These adjustment costs happen when the firm increases or decreases its committed resources. Kama and Weiss (2010) also mention that an earning target could be a trigger for firms' cost saving. As a result, the degree of cost stickiness will decrease. According to Chen et al. (2012), the degree of cost stickiness could be influenced by the agency problem considering the amount of incentive to the management measured by free cash flow (FCF). Higher FCF could increase the management's opportunity to overinvest in operating costs in response to an increase in output demand and to delay the cutting of operating costs in response to a decrease in output demand. This condition is called a management empire building phenomenon, which could distort the cost behavior. On the other hand, Calleja et al. (2006) find that leverage increases the creditor's control of management in administering the firm's costs. Therefore, leverage affects the stickiness of cost behavior.

This study replicates the model in the previous studies. The objectives of the study are to investigate the cost stickiness behavior in operational costs, especially Sales and General Administrative (SandGA) Costs, and to find the determinants of this cost stickiness. 


\section{LITERATURE REVIEW}

One of the basic concepts in cost accounting is cost behavior. In general, cost behavior relates to how cost responds to change in activities and volume. Many types of costs could respond proportionally, but some are independent with a change in activities and volume. Cost behavior is classified into fixed cost, variable cost, and semi-variable cost (Anderson and Raiborn, 1977; Carter and Usry, 2002).

1. Fixed Cost is the cost which remains constant within a relevant range of activities although there is fluctuation in business operations.

2. Variable Cost is the cost which will change in direct proportion to the changes in volume or activity.

3. Semi-variable Cost is the combination of variable and fixed costs in terms of characteristics.

Related to cost behavior, existing empirical studies find that some of the costs in a company might not respond proportionally to the change in volume and activity. It means that those costs will increase when the volume and activity increase, either larger or smaller than the decrease in costs when the volume and activity decreases. This cost behavior is called cost stickiness. Prior research by Anderson et al. (2003), Chen et al. (2012), Bruggen and Zehnder (2014), and Venieris et al. (2015) find cost stickiness behavior on sales, general, and administrative costs. On the other hand, Calleja et al. (2012) state that operating costs in companies have sticky behavior. In Indonesia, research done by Hidayatullah et al. (2011) and by Windyastuti (2013) demonstrates that sticky cost behavior on sales, general, and administrative costs is in tune with change in sales.

Cost stickiness is defined as asymmetric cost behavior because the relative magnitude of an increase in costs for an increase in sales is greater than the relative magnitude of decrease in costs for a decrease in sales (Anderson et al., 2003). Bruggen and Zehnder state that cost stickiness is cost behavior which depends on a change in managerial decision making, especially when sales revenue decreases. The sticky cost behavior tends to rise in the short term but will not automatically decline along with a decrease in the activity (Mak and Roush, 1994 in Baumgarten, 2012). Instead of the cost stickiness phenomenon, the cost behavior could lead to cost anti-stickiness which occurs when the increase in costs caused by the increase in the activity is smaller than the decrease in costs resulting from the decrease in the activity. To explain more about this cost behavior, Figure 1 shows asymmetric cost behavior according to Balakrishnan et al., (2004).

One of the main reasons for cost stickiness behavior is that there is committed resources cost adjustment in a company, which is not based on a degree of change in business activities

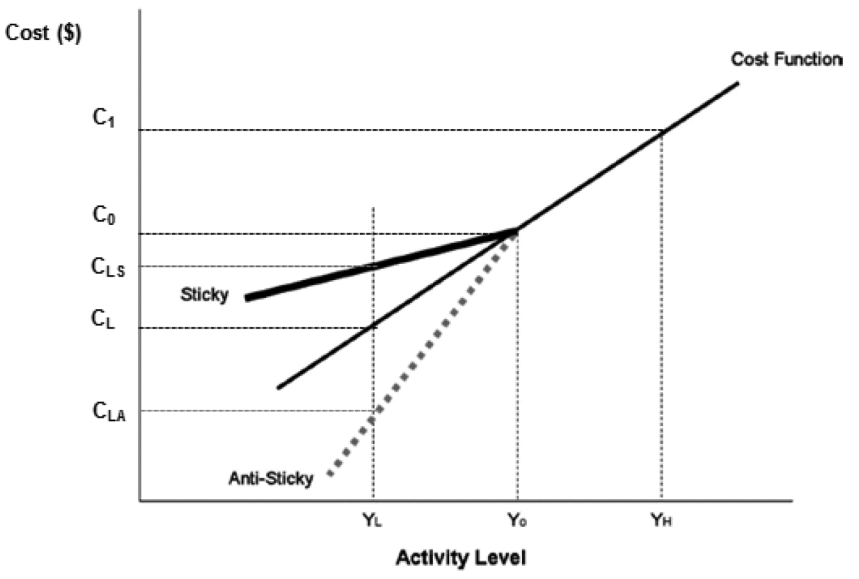

Figure 1. Asymmetric cost behavior function.

Source: Balakrishnan (2004). 
(Guenther et al., 2014). This happens when the management is involved in the resources adjustment process, especially through their decisions and intentions for the company. Anderson et al. (2003) state that there are two main arguments why the management would not decrease the company's costs when the business activities are declining. Firstly, there could be adjustment costs which are the potential cause of cost stickiness because when demand declines, managers are faced with a trade-off between the costs of retaining redundant resources on the one hand, and resource-adjustment costs on the other hand. Secondly, the management has their individual considerations as well as personal interests. Another reason stated by Guenther et al. (2014) is that cost stickiness could occur from several factors, such as:

1. Laws and regulations

2. Corporate social and personnel policy

3. Firm and operating policy

4. Psychological and agency-related reasons.

After explaining the reasons for sticky cost behavior, Baumgarten (2012) mentions the characteristics relating to cost stickiness:

1. General characteristics of cost stickiness.

2. Firm-specific characteristics of cost stickiness.

3. Industry-specific characteristics of cost stickiness.

4. Country-specific characteristics of cost stickiness.

Based on previous studies, there are several factors affecting the level of cost stickiness. These factors include firm-specific adjustment costs, earnings target, management empire-building state incentives, agency problem, and other factors. The firm-specific adjustment cost is measured by asset intensity and employee intensity. Earnings target is measured by return on equity (ROE). Management empire-building states incentives could be indicated by free cash flow (FCF). Agency problem is measured by the company's leverage. Finally, other factors are measured by GDP growth. Figure 2 shows the conceptual framework for this research.

Related to the cost stickiness phenomenon, there are several hypotheses developed in this research. First, the cost that will be tested includes the sales, general, and administrative (SG\&A) costs (Anderson et al., 2003).

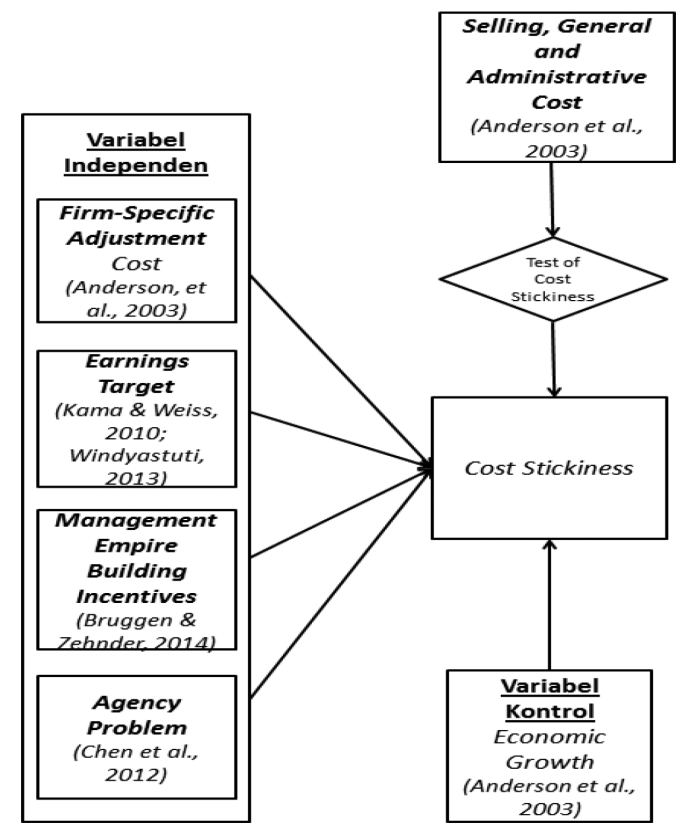

Figure 2. Conceptual framework. 
H1a: The magnitude of an increase in SG\&A costs for an increase in net sales is greater than the magnitude of a decrease in SG\&A costs for a decrease in net sales.

Secondly, the company's resources related to assets and employees will be tested as one of the factors affecting the degree of cost stickiness. Those variables are indicated by asset intensity and employee intensity. Thus, the hypothesis could be derived as follows:

H2a: Asset intensity has a positive impact on the level of cost stickiness.

H3a: Employee intensity has a positive impact on the level of cost stickiness.

In addition, the level of cost stickiness is influenced by earnings target. Calleja et al. (2006) show that the earning target through return on equity (ROE) causes a decrease in the degree of cost stickiness in many companies in Germany. Kama and Weiss (2010) find that the profit target could motivate the management to achieve cost saving when sales are declining. Based on those studies, the hypothesis is:

H4a: Earnings target has a negative impact on the level of cost stickiness.

Chen et al. (2012) express that when the level of free cash flow (FCF) is high, the management has the opportunity to get empire-building incentives causing over-investment in operating costs. As a result, free cash flow (FCF) as an indicator of management empire-building incentives is related to the degree of cost stickiness.

H5a: Free cash flow has a positive impact on the level of cost stickiness.

The last main factor in this research is the agency problem. Calleja et al. (2006) discover that higher debt intensity in companies could lead to asymmetric cost behavior. Furthermore, Xue and Hong (2015) state that leverage in companies could improve the companies' performance as well as corporate governance which will minimize the distortion of cost behavior coming from discretionary management.

H6a: Leverage has a negative impact on the level of cost stickiness.

\section{RESEARCH METHOD}

The sample used for this research is manufacturing companies listed in Indonesia Stock Exchange (IDX) ten years starting from 2005 to 2014. Manufacturing companies are chosen because they have various types of costs compared to other industries. This research constitutes quantitative research using multiple regressions through the pool least square method. The research model is developed from previous studies. Variables to be tested are the ratio of sales, the general and administrative expenses as a proxy to measure the degree of cost stickiness, and the ratio of net sales as the main factor which determines the sticky cost behavior (Anderson et al., 2003). Other variables are asset intensity, employee intensity, return on equity, free cash flow, and leverage. There is one control variable used, namely the GDP growth. The research models are presented below:

Model 1.

$$
\log \left[\frac{S G \& A_{i, t}}{S G \& A_{i, t-1}}\right]=\beta_{0}+\beta_{1} \log \left[\frac{\text { Sales }_{i, t}}{\text { Sales }_{i, t-1}}\right]+\beta_{2} * \text { DecDummy }_{i, t} * \log \left[\frac{\text { Sales }_{i, t}}{\text { Sales }_{i, t-1}}\right]+\varepsilon_{i, t}
$$

Model 2.

$$
\begin{aligned}
\log \left[\frac{S G \& A_{i, t}}{S G \& A_{i, t-1}}\right]= & \beta_{0}+\beta_{1} \log \left[\frac{\text { Sales }_{i, t}}{\text { Sales }_{i, t-1}}\right]+\beta_{2} * \text { Decrease Dummy }_{i, t}^{*} \log \left[\frac{\text { Sales }_{i, t}}{\text { Sales }_{i, t-1}}\right] \\
& +\sum_{m=3}^{Z} \beta_{m}^{*} \text { Decrease Dummy }_{i, t} * \log \left[\frac{\text { Sales }_{i, t}}{\text { Sales }_{i, t-1}}\right] * \text { Factors }_{m, i, t}+\varepsilon_{i, 1}
\end{aligned}
$$


Factors in model 2 are asset intensity, employee intensity, return on equity, free cash flow, leverage, and GDP growth. Asset Intensity is measured by the logarithm of the ratio of total assets to net sales. Employee Intensity is measured by the logarithm of the ratio of the number of employees to net sales. Return on Equity is derived from the ratio of EBIT to equity. Free Cash Flow is calculated from cash flow from operation minus dividend and divided by total assets. GDP growth is measured by the percentage of yearly GDP growth. Finally, leverage is simply the ratio of total debt to total assets.

In addition to the research, the robustness of the test will be achieved by changing SG\&A expenses with total operating costs. Finally, to test the factors, the interaction or moderation effects between variables will be eliminated.

Model 3.

$$
\log \left[\frac{T C_{i, t}}{T C_{i, t-1}}\right]=\beta_{0}+\beta_{1} \log \left[\frac{\text { Sales }_{i, t}}{\text { Sales }_{i, t-1}}\right]+\beta_{2} * \text { DecDummy }_{i, t} * \log \left[\frac{\text { Sales }_{i, t}}{\text { Sales }_{i, t-1}}\right]+\varepsilon_{i, 1}
$$

Model 4.

$$
\begin{aligned}
& \text { STICKINESSit }=\beta 0+\beta 1 \text { SALESCHGit }+\beta 2 \text { DECDUMit } * \text { SALESCHGit }+ \\
& \beta 3 \text { ASSETit }+\beta 4 \text { EMPLOYEEit }+\beta \text { ROEit }+\beta 6 \text { FCFit }+\beta \text { LEVit }+\beta 8 \text { GDPit }+\varepsilon i t
\end{aligned}
$$

This research has also been tested for any possible multicollinearity, heteroscedasticity, and autocorrelation for all models. Based on the test, this research is free from those classical assumptions.

\subsection{Empirical tests}

The first empirical testing is about descriptive statistics as shown in Tables 1 and 2,

Table 1. Descriptive statistics of net sales and $S G \& A$ costs.

\begin{tabular}{lccccc}
\hline & Mean & Median & Max & Min & Std. Dev. \\
\hline Sales (in billion Rupiah) & $5,346.07$ & $1,196.65$ & $201,701.00$ & 29.23 & $15,656.69$ \\
SG\&A Costs (in billion Rupiah) & 526.15 & 85.98 & $17,885.00$ & 1.05 & $1,490.20$ \\
SG\&A Costs/Sales (\%) & $11.30 \%$ & $7.85 \%$ & $96.92 \%$ & $0.48 \%$ & $11.20 \%$ \\
\hline
\end{tabular}

Table 2. Descriptive statistics of variables.

\begin{tabular}{lccccc}
\hline Variable & \multicolumn{1}{l}{ Mean } & Median & Max & Min & Std. Dev. \\
\hline STICKINESS & 0.03399 & 0.04232 & 0.96310 & -0.75358 & 0.18306 \\
SALESCHG & 0.05017 & 0.05222 & 1.19132 & -0.59127 & 0.11004 \\
DECDUM & 0.21748 & 0 & 1 & 0 & 0.41273 \\
DECDUM ${ }^{*} S A L E S C H G$ & -0.01814 & 0 & 0 & -0.59127 & 0.05365 \\
ASSET & -0.03033 & -0.03395 & 0.72397 & -1.20104 & 0.23321 \\
DECDUM ${ }^{*} S A L E S C H G^{*}$ ASSET & -0.00129 & 0 & 0.17198 & -0.16920 & 0.01694 \\
EMPLOYEE & -2.98511 & -2.98458 & -1.80370 & -4.86838 & 0.43187 \\
DECDUM ${ }^{*} S A L E S C H G^{*} E M P L O Y E E$ & 0.05325 & 0 & 1.67481 & 0 & 0.15930 \\
ROE & 0.15957 & 0.12828 & 4.45089 & -5.95062 & 0.47583 \\
DECDUM ${ }^{*} S A L E S C H G^{*}$ ROE & -0.00003 & 0 & 0.79512 & -0.20728 & 0.03101 \\
FCF & 0.00598 & 0.00315 & 2.55886 & -1.07237 & 0.15481 \\
DECDUM ${ }^{*} S A L E S C H G^{*} F C F$ & -0.00040 & 0 & 0.06304 & -0.07790 & 0.00628 \\
\hline
\end{tabular}


Table 3 describes the result of the level of cost stickiness in SG\&A costs. The coefficient and expected signs indicate that there is cost stickiness in SG\&A costs.

Table 4 shows the result of testing factors that influence the level of cost stickiness as well as the answer to the previous hypothesis. In general, the value of coefficients for all variables is the same as the expected sign except for the GDP variable. These results indicate that each factor of cost stickiness has either a positive or negative impact on the level of cost stickiness.

To analyze the result of the robustness testing, Tables 5 and 6 exhibit the summary. Table 5 shows that the variable of SG\&A costs is replaced by operating costs. In Table 6 , the factors of cost stickiness are re-tested by eliminating the moderating impact of each variable.

Table 3. Regression testing results of the first model.

\begin{tabular}{lllrlll}
\hline Variable & & Expected sign & Coeff. & Std. error & t-stat & Prob. \\
\hline C & $\beta 0$ & & -0.0086 & 0.0049 & -1.7494 & $0.0805^{*}$ \\
SALESCHG & $\beta 1$ & + & 0.7259 & 0.0448 & 16.1992 & $0.0000^{* * *}$ \\
DECDUM*SALESCHG & $\beta 2$ & - & -0.1567 & 0.0968 & -1.6564 & $0.0979^{*}$ \\
R-squared & & 0.2867 & & & & \\
Adjusted R-squared & & 0.2853 & & & & \\
F-statistic & & 206.423 & & & & \\
Prob (F-Statistic) & & 0.0000 & & & & \\
\hline
\end{tabular}

Table 4. Regression testing results of the second model.

\begin{tabular}{|c|c|c|c|c|c|c|}
\hline Variable & & $\begin{array}{l}\text { Expected } \\
\text { sign }\end{array}$ & Coeff. & $\begin{array}{l}\text { Std. } \\
\text { Error }\end{array}$ & t-stat & Prob. \\
\hline$C$ & $\beta 0$ & & -0.0137 & 0.0039 & -3.4789 & $0.0005 * * *$ \\
\hline SALESCHG & $\beta 1$ & + & 0.7541 & 0.0361 & 20.8660 & $0.0000^{* * *}$ \\
\hline$D E C D U M^{*} S A L E S C H G$ & $\beta 2$ & - & -0.2128 & 0.1308 & -1.6267 & 0.1042 \\
\hline$D E C D U M^{*} S A L E S C H G * A S S E T$ & $\beta 3$ & - & -0.4135 & 0.1696 & -2.4382 & $0.015^{* *}$ \\
\hline$D E C D U M^{*} S A L E S C H G{ }^{*} E M P L O Y E E$ & $\beta 4$ & - & -0.0742 & 0.0176 & -4.2062 & $0.000 * * *$ \\
\hline$D E C D U M^{*} S A L E S C H G^{*} R O E$ & $\beta 5$ & + & 0.1170 & 0.0704 & 1.6611 & $0.0971^{*}$ \\
\hline$D E C D U M^{*} S A L E S C H G^{*} F C F$ & $\beta 6$ & - & -0.6076 & 0.7313 & -0.8309 & 0.4063 \\
\hline$D E C D U M^{*} S A L E S C H G^{*} L E V$ & $\beta 7$ & + & 0.6439 & 0.2686 & 2.3973 & $0.0167 * *$ \\
\hline$D E C D U M^{*} S A L E S C H G^{*} G D P$ & $\beta 8$ & - & 0.5468 & 0.3887 & 1.4068 & 0.1599 \\
\hline R-square & & 0.5159 & & & & \\
\hline Adjusted R-square & & 0.5111 & & & & \\
\hline F-statistic & & 108.563 & & & & \\
\hline Prob (F-Statistic) & & 0.0000 & & & & \\
\hline
\end{tabular}

Table 5. Result of robustness testing for the third model.

\begin{tabular}{|c|c|c|c|c|c|c|}
\hline \multicolumn{2}{|l|}{ Variable } & \multirow[t]{2}{*}{ Expected sign } & \multirow{2}{*}{$\begin{array}{l}\text { Coeff. } \\
0.0011\end{array}$} & \multirow{2}{*}{$\frac{\text { Std. error }}{0.0006}$} & \multirow{2}{*}{$\frac{\text { t-stat }}{1.7293}$} & \multirow{2}{*}{$\begin{array}{l}\text { Prob. } \\
0.0841\end{array}$} \\
\hline $\mathrm{C}$ & $\beta 0$ & & & & & \\
\hline SALESCHG & $\beta 1$ & + & 0.9898 & 0.0071 & 139.6679 & $0.0000^{* * *}$ \\
\hline DECDUM*SALESCHG & $\beta 2$ & - & 0.0055 & 0.0176 & 0.3143 & 0.7534 \\
\hline R-squared & & 0.9683 & & & & \\
\hline Adjusted R-squared & & 0.9683 & & & & \\
\hline F-statistic & & 15702.08 & & & & \\
\hline Prob (F-Statistic) & & 0.0000 & & & & \\
\hline
\end{tabular}


Table 6. Result of robustness testing for the fourth model.

\begin{tabular}{|c|c|c|c|c|c|c|}
\hline Variable & & $\begin{array}{l}\text { Expected } \\
\text { sign }\end{array}$ & Coeff. & Std. error & t-stat & Prob. \\
\hline $\mathrm{C}$ & $\beta 0$ & & 0.0560 & 0.0282 & 1.9861 & 0.0473 \\
\hline SALESCHG & $\beta 1$ & + & 0.7273 & 0.0455 & 15.9724 & $0.0000 * * *$ \\
\hline DECDUM*SALESCHG & $\beta 2$ & - & -0.2001 & 0.0979 & -2.0438 & $0.0412^{* *}$ \\
\hline ASSET & $\beta 3$ & + & 0.0313 & 0.0175 & -1.7883 & $0.074 *$ \\
\hline EMPLOYEE & $\beta 4$ & + & 0.0221 & 0.0090 & 2.4618 & $0.014 * *$ \\
\hline $\mathrm{ROE}$ & $\beta 5$ & - & -0.0030 & 0.0070 & -0.4307 & 0.6668 \\
\hline $\mathrm{FCF}$ & $\beta 6$ & + & -0.0303 & 0.0277 & -1.0936 & 0.2744 \\
\hline LEV & $\beta 7$ & - & 0.0008 & 0.0157 & 0.0482 & 0.9616 \\
\hline GDP & $\beta 8$ & + & 0.0203 & 0.0246 & 0.8277 & 0.4080 \\
\hline R-squared & & 0.2940 & & & & \\
\hline Adjusted R-squared & & 0.2884 & & & & \\
\hline F-statistic & & 53.13627 & & & & \\
\hline Prob (F-Statistic) & & 0.0000 & & & & \\
\hline
\end{tabular}

\section{RESULT AND DISCUSSION}

According to Table 3, the coefficient of saleschg $(\beta 1)$ is 0.7259 and decdum*saleschg $(\beta 2)$ has the value -0.1567 . Each of the variables has a significant result in terms of $t$-stat. Previous studies state that the hypothesis will be accepted if $\beta 1>\beta 1+\beta 2$ or if $\beta 1>0$ and $\beta 2<0$. Anderson et al. (2003) express that the value of $\beta 1$ indicates an increase in SG\&A costs when sales are high. Meanwhile, $\beta 1+\beta 2$ denote a decrease in SG\&A costs when sales are declining. Therefore, based on the regression testing result, when net sales increase by $1 \%$, SG\&A costs will rise by $0.73 \%$. On the other hand, when net sales decrease by $1 \%$, SG\&A costs will decrease by $0.57 \%$. Based on this condition, $H_{0}$ is rejected. The accepted hypothesis is that the magnitude of an increase in SG\&A costs for an increase in net sales is greater than the magnitude of a decrease in SG\&A costs for a decrease in net sales. The result of this study is consistent with the previous research by Anderson et al. (2003), Windyastuti (2010), Hidayatullah et al. (2011), Chen et al. (2012), Bruggen and Zehnder (2014), and also Venireis et al. (2015).

To determine the factors affecting the level of cost stickiness, Table 4 presents the result of regressions. The first factor is asset intensity. Based on Table 4, the coefficient of $\beta 3$ is -0.4135 and is significant at the $95 \%$ confidence level. It could be inferred that when net sales increase by $1 \%$, SG\&A costs will rise by $0.75 \%$, and also when net sales decrease by $1 \%$ related to asset intensity, SG\&A costs will decrease by $0.34 \%$. The hypothesis that states that asset intensity has positive impact on the level of cost stickiness could be accepted. This result supports the previous studies by Anderson et al. (2003), Calleja et al. (2006), Anderson and Lenan (2007), Chen et al. (2012).

The second factor is employee intensity. In Table 4 , the value of $\beta 4$ is -0.0742 and is significant at the $99 \%$ confidence level. This condition shows that when net sales increase by $1 \%$, SG\&A costs will rise by $0.75 \%$, and when net sales decrease by $1 \%$ related to employee intensity, SG\&A costs will decrease by $0.68 \%$. As the number of employees in a company grows, the cost stickiness will rise. The hypothesis that states that employee intensity has a positive impact on the level of cost stickiness could be accepted. This result is consistent with Anderson et al. (2003), Calleja et al. (2006), and also Venieris et al. (2015).

The third factor is the earning target measured by return on equity. Table 4 shows that coefficient of $\beta 5$ has a value of 0.1170 and is significant at the $90 \%$ confidence level. This result denotes that when net sales increase by $1 \%$, SG\&A costs will rise by $0.75 \%$, and when net sales decrease by $1 \%$ related to return on equity, SG\&A costs will decrease by $0.87 \%$. The earning target from return on equity causes a decrease in the level of cost stickiness. 
SG\&A costs have anti-sticky behavior since the decrease in costs when net sales are declining is greater than the increase in costs when net sales increase. As a result, the hypothesis that states that the earning target has a negative impact on the level of cost stickiness could be accepted.

The next factor is management empire-building state incentive, which is measured by free cash flow (FCF). Table 4 shows that $\beta 6$ has a value of -0.6076 . It means that when net sales increase by $1 \%$, SG\&A costs will rise by $0.75 \%$ and also when net sales decrease by $1 \%$ in relation with free cash flow, SG\&A costs will decrease by $0.15 \%$ but not significant. As a result, the hypothesis that states that free cash flow has a positive impact on the level of cost stickiness could not be accepted. This result is not consistent with studies done by Chen et al. (2012) and Venieris et al. (2015).

The last main factor is leverage. Based on Table 4, the value of $\beta 7$ is 0.6439 and is significant at the $95 \%$ confidence level. Therefore, when net sales increase by $1 \%$, SG\&A costs will rise by $0.75 \%$, and when net sales decrease by $1 \%$ in relation with leverage, SG\&A costs will decrease by $1.34 \%$. The level of cost stickiness decreases, and SG\&A costs have anti-sticky behavior when the company has higher leverage. Hence, the hypothesis that states that leverage has a negative impact on the level of cost stickiness could be accepted. This result is in line with Calleja et al. (2006).

In relation with control variables, according to Table 4 , the coefficient of $\beta 8$ is 0.5468 with t-statistic 0.1599 . It means that GDP growth does not have significant influence on the level of cost stickiness.

As part of robustness testing, there are two models to be tested. The first testing is summarized in Table 5. Meanwhile, the second testing is shown in Table 6. Based on Table 5, the value of saleschg $(\beta 1)$ is 0.9898 and the coefficient variable decdum*saleschg $(\beta 2)$ is 0.0055 . It can be concluded that when net sales increase by $1 \%$, operating costs will rise by $0.99 \%$, but when net sales decrease by $1 \%$, operating costs will decrease by $1 \%$ and not in a significant level. This condition demonstrates that operating costs have proportional cost behavior to the change of sales. This is the same with the variable of cost behavior in general. As a result, operating cost does not have any cost stickiness behavior.

Then, referring to Table 6 , there are some results regarding factors of cost stickiness which are without a moderation variable to the change of net sales. The cost stickiness of SG\&A in this model is still consistent with the first model. In addition, only two variables have consistent outcome with the main research model, namely asset intensity and employee intensity. Both variables have a positive impact on the level of cost stickiness. Return on the equity variable has the same expected sign but not significant statistically. The other variables, namely free cash flow, leverage, and GDP growth, do not have any impact on the degree of cost stickiness.

Overall, the value of coefficients according to Table 6 is less than $1 \%$ for the factors of cost stickiness. This shows that determinants with no interaction with a change in sales have less relation and influence to SG\&A cost stickiness behavior. The existence of moderation or interaction variables could substantiate the influence of cost stickiness factors.

\section{CONCLUSION}

The result of this research can be concluded in two main points. First, cost stickiness behavior could be found on sales, general, and administrative costs. However, the operating cost does not have sticky cost behavior. Second, factors that affect the level of cost stickiness are asset intensity, employee intensity, earnings target, and leverage, and this is consistent with the previous studies.

\section{REFERENCES}

Anderson, Henry R., and Mitchell H. Raiborn. 1977. Basic Cost Accounting Concept. Boston: Houghton Mifflin Company. 
Anderson, Mark C., Rajiv D. Banker, and Surya N. Janakiraman. 2003. Are Selling, General and Administrative Costs "Sticky"?. Journal of Accounting Research 41: 47-63.

Anderson, Shannon W., and William N. Lanen. 2007. "Understanding Cost Management: What Can We Learn from the Empirical Evidence on "Sticky Costs"?." Working Paper. http://papers.ssrn.com/ sol3/papers.cfm?abstract_id $=975135$

Balakrishnan, Ramji, Michael J. Petersen, and Naomi S. Soderstrom. 2004. "Does Capacity Utilization Affect the 'Stickiness' of Cost?.” Journal of Accounting, Auditing, and Finance 19(3): 283-299.

Baumgarten, Daniel. 2012. "The Cost Stickiness Phenomenon: Causes, Characteristics, and Implications for Fundamental Analysis and Financial Analysts' Forecasts." PhD Dissertation, University of Cologne. Germany: Springer Fachmedien Wiesbaden.

Baumgarten, Daniel. 2012. The Cost Stickiness Phenomenon. Gabler Verlag: Springer Fachmedien Wiesbaden.

Bruggen, Alexander and J.O. Zehnder. 2014. SG\&A Cost Stickiness and Equity-Based Executive Compensation: Does Empire Building Matter?. Journal of Management Control 25: 169-192.

Calleja, K.enneth, Michael Steliaros and Dylan C. Thomas. 2006. A Note of Cost Stickiness: Some International Comparison. Management Accounting Research 22: 1-22.

Carter, William K., and Milton F. Usry. 2002. Cost Accounting (13th edition). Ohio: Thomson Learning Custom Publishing.

Chen, Clara X., Hai Lu, and Theodore Sougiannis. 2012. The Agency Problem, Corporate Governance, and the Asymmetrical Behavior of Selling, General, and Administrative Costs. Contemporary Accounting Research 29: 252-282.

Cooper, Robin, and Robert S. Kaplan. 1998. The Design of Costs Management Systems: Text, Cases, and Readings. Upper Saddle River, NJ: Prentice Hall.

Guenther, Thomas W., Anja Riehl, and Richard Robler. 2014. Cost Stickiness: State of the Art of Research and Implications. Journal Management Control 24: 301-318.

Hidayatullah, Idi J., Wiwik Utami, and Yudhi Herliansyah. 2011. Analisis Perilaku Sticky Cost and Pengaruhnya terhadap Prediksi Laba Menggunakan Model Cost Variability and Cost Stickiness (CVCS) pada Emiten di BEI untuk Industri Manufaktur. Banjarmasin: Simposium Nasional Akuntansi 15.

Kama, Itay and Dan Weiss. 2010. "Do managers' Deliberate Decisions Induce Sticky Cost?" Working Paper. http://ssrn.com/abstract $=2148888$.

Nachrowi, Nachrowi D. and Hardius Usman. 2006. Pendekatan Populer and Praktis Ekonometrika untuk Analisis Ekonomi and Keuangan. Jakarta: Lembaga Penerbit FEUI.

Noreen, Eric. 1991. Conditions under which Activity-Based Cost Systems Provide Relevant Costs. Journal of Management Accounting Research 3: 159-68.

Pervan, Maja, and Pervan, Ivica. 2012. "Analysis of Sticky Cost: Croatian Evidence." Working Paper. http://www.wseas.us/e-library/conferences/2012/Porto/AEBD/AEBD-23.pdf.

Venieris, George, Naoum, Vasilos Christos, and Orestes Vlismas. 2015. Organization Capital and Sticky Cost Behavior of Selling, General, and Administrative Expenses. Management Accounting Research 26: $54-82$.

Windyastuti. 2013. Penetapan Target terhadap Stickiness Cost. Jurnal Keuangan and Perbankan 17: 71-77.

Xue, Shuang and Yun Hong. 2015. Earnings Management, Corporate Governance, and Expense Stickiness. China Journal of Accounting Research 9 (1): 41-58. 